\title{
Haunted Intimacy: Spectral and Vital Space within a Historic House Museum
}

\author{
Marisa Karyl Franz
}

\begin{abstract}
Merchant's House Museum is haunted. While it functions as a historic house museum in Manhattan, the house remains the home of the Tredwell family who now appear as ghosts. For the museum, these ghosts become animating presences, continuing to keep the everyday things of the house embedded in the intimate space of a family's home. Throughout this article, I explore how those connected to the house as staff, visitors, and volunteers present the ghosts of the Tredwells and, based on these peoples' experiences, I examine the Tredwell house within a museological framework of, what I term, haunted intimacy, that keeps the house in vital relation to the family.
\end{abstract}

Key words: ghosts; home; historic house museums; intimacy; haunting

Merchant's House Museum is haunted. A historic house in New York City, Merchant's House Museum is a red brick row house built in the late Federal style with a Greek revival interior. ${ }^{1}$ The rooms are curated to recreate the domestic landscape of the Tredwell family, who lived in the home from 1835 to 1906 . While the house operates as a museum documenting the lives of a past family, the staff also present the house as continuing to be the home of the ghosts of the Tredwell family. Spectral presences appear in hallways, play the piano, smoke cigars, and sometimes answer questions during paranormal investigations and seances hosted by the museum. The staff interpret the house and its ghosts through the lens of what I term haunted intimacy, where ghosts exert a personal and relational presence to the material world; hauntings invite the living into an affective and sympathetic relationship to the space and the past.

Historic house museums have been charged with being the 'sleepiest corner of the museum world' where 'museum stewards usually re-present the house not as a place for living, but rather as a container for collections' (Vagnone and Ryan 2016: 11; 35). Merchant's House Museum, however, is actively pursuing a more vital presence through the hauntings. The objects that the family lived with rest in spaces that they inhabited, and in their death, the Tredwells continually animate their home. Haunted intimacy as opposed to sensationalism frames the ongoing and everyday relationship between the stewards of the house, the original family, and visitors. It has become part of the museum's public programming, site interpretation, and conservation work.

Throughout this article, I discuss the ghosts at Merchant's House as real. In this, I draw on the work of anthropologists who argue for the ontological value of divergent realities. Holbraad and Pedersen write, the methodology of the new ontological turn 'is not so much a matter of "seeing differently" ... It is above all a matter of seeing different things' (Holbraad and Pedersen 2017: 6). Here, ethnographic work uncovers not simply an epistemic system that makes sense of the world in a different way, but rather accepts the ontic truth of this system. By engaging with the ghosts as ontologically real, we are able to engage with them as participants in the museum who have demands and desires that sustain and shift after death. While there has been substantial scholarship that addresses ghosts and spectrality, I approach the haunting of Merchant's House as cultivating a particular type of intimacy where the ghosts relate to the museum collections as personal and still embedded in the affective 
lives of the deceased family, thereby inviting the living to also see the house and its material collections as continuing and relational. Death is not isolated in the house, but pervasive and welcomed as part of the living experience. In this article, I begin with a discussion of spectrality and haunting to challenge Derrida's claim that 'There has never been a scholar who really, and as a scholar, deals with ghosts' (Derrida [1994] 2006: 12). Next, I consider the particular history of the Tredwell home as a haunted house and its transition into a museum that has developed a museological practice of haunted intimacy that informs the work of staff, the experiences of visitors, and the continued lives of the dead.

\section{Ghosts and Hauntings}

Much of the scholarship in spectral studies emphasizes the metaphoric and symbolic nature of ghosts, suggesting that behind them is a negotiation with the histories of trauma, violence, oppression, and neglect (Freccero 2007; Gordon [1997] 2008, Oram 2012). For Avery Gordon, the ontological status of ghosts is dependent on human actors; Gordon writes, 'to write ghost stories implies that ghosts are real, that is to say, that they produce material effects' (Gordon [1997] 2008: 17). At Merchant's House, the ghosts are not only realized through the stories told and retold in the house; they have impacts on the house, the collections, the staff, and the visitor. The material effects of the ghosts are narrated in the stories that are told about them and through the affective relationships that configure the liminal space of home and museum as vital. This haunted intimacy rejects the death frame of the historic house, and instead invites an affective relationship with the deceased family. These ghosts are not part of the tourism landscape termed 'haunted heritage' by Michele Hanks, which relies principally on ghosts whose 'lives and stories' appear '.... as a matter of local, regional, or national history rather than family history' (Hanks 2015: 13).

Diverse scholarship has developed from spectral studies to explore haunted heritage and tourism sites (Inglis and Holmes 2003; Miles 2015; Bucior 2020; Kolk 2020). Frequently, these works address ghosts as part of a haunted modernity, where, as Avery Gordon demonstrates, haunting is rooted in fear and 'always registers the harm inflicted or the loss sustained by a social violence done in the past or in the present... the domain of turmoil and trouble...' (Gordon [1997] 2008: xvi). Gordon, working with literary texts, draws this traumatic haunting from works such as Toni Morrison's Beloved that opens '124 was spiteful' (Morrison [1987] 2004: 3), a house of a two-fold haunting where the living and the dead are haunted, where 'neither Sethe nor the others can perceive that the ghost that is haunting them is haunted herself' (Gordon [1997] 2008: 140). Gordon and Morrison explore the history of enslavement in the language of haunting as a manifestation of trauma, including generational trauma. The intimacy with the ghosts and the home described by those at Merchant's House diverges from more public examples that often narrate collective trauma as instances of pervasive violence. Instead, we are drawn into the haunted house as a domestic space, a space that is particular to the histories of a prosperous white family in a house bought by Seabury Tredwell. Rather than historical or social trauma, we encounter the personal and intimate experiences of a family with all the ambiguities of home and life. In Co-Habiting with Ghosts: Knowledge, Experience, Belief and the Domestic Uncanny, Carol Lipman considers these ambiguities through her attention to the different natures of the home as simultaneously a physical place and an idea, promptingfeelings of intimacy and alienation (Lipman 2014: 8-9). The home, at once a place of comfort and confinement, of potential kindness and violence, is entangled in the haunted intimacy articulated by staff and volunteers at Merchant's House. The staff and volunteers explain that there is a pull to the museum and the unique experiences of immersive and affective space of the nineteenth-century home. ${ }^{2}$ This emotional and embodied tugging towards the haunted house echoes Gordon's explanation of hauntings, 'being haunted draws us affectively, sometimes against our will and always a bit magically, into the structure of feeling a reality we come to experience, not as cold knowledge, but as transformative recognition'; here, Gordon reminds us that haunting is an experience that draws us into a place, as if by magic, to alter something about us that is embodied and affectively powerful (Gordon [1997] 2008: 8). 


\section{Merchant's House: A History of a Home and Haunting}

The foundations of spectral intimacy emerge from the history of the home. As a museum of the Tredwells' home, Merchant's House exposes the intimacy of a family's life through the things they left behind. These objects include a book given as a Christmas gift by the eldest daughter, Elizabeth, to her sister Phebe; a dress that was left half-altered with the sleeves removed; a rosewood piano; and Luis Walton's carte-de-visite that remained in the house past the death of Gertrude, the youngest daughter and last resident in the Tredwell home. ${ }^{3}$ These material records of the Tredwell's life gain a new relational life in the space of haunting, becoming active things that continue to have meaning and affective value in the context of the family home. Judith Richardson, in her book Possessions: The History and Uses of Haunting in the Hudson Valley, explains how haunting gathers around certain types of memories and mementos, writing, 'ghosts operate as a particular, and peculiar, kind of social memory, an alternate form of history-making in which things usually forgotten, discarded, or repressed become foregrounded' (Richardson 2003: 3). The everyday space of the Tredwell home is indeed foregrounded as the liminal space of haunting. In Virginia Woolf's short story 'A Haunted House' a similar intimacy mediated through physical objects is seen as a living couple traces the movements of an invisible ghostly couple who inhabited the house. The relationship between the two couples is not fearful or malevolent; rather, we see the layering of spectral memory as the ghostly couple searches for, what we learn at the end, is the intimacy of their lives, which they find when looking upon the living couple asleep. Throughout, we read the growing refrain 'safe, safe, safe' beating in the 'heart of the house' (Woolf 1921: 6-7).

At Merchant's House, the ghosts pull the living into the intimate material space of the home. The ghosts seemingly stay in their own domestic space as a place that is theirs, while trusting it to the care of its current stewards who keep it safe. Dan Sturges, the paranormal investigator who has worked with Merchant's House since 2008, explains that ghosts know 'we're taking care of the house', and both the ghosts and the staff love the house, keeping it and the things inside it in a vital relationship of intimacy and care. ${ }^{4}$ Gaston Bachelard described the phenomenology of the physical and conceptual home in The Poetics of Space as 'how we inhabit our vital space, in accord with all the dialectics of life, how we take root, day after day, in a "corner of the world." For our house is our corner of the world' (Bachelard 2014: 26). In this conceptualization of the house, the materiality of the home binds the self to the world: 'without it, man would be a dispersed being'. For Bachelard, the anchoring of the self can occur through a liminal phenomenology of dreams, since 'when we dream of the house we were born in, in the utmost depth of reverie, we participate in this original warmth, in this well-tempered matter of the material paradise' (Bachelard 2014: 29).

At Merchant's House, domestic objects that are usually forgotten or discarded are catalogued, conserved and cared for - they are kept safe. Thus, the haunted intimacy of Merchant's House embeds the museum in a space of domestic intimacy and home. Ghosts of place can be 'rooted, friendly, and affirming - and they are never dead, although they may be of the dead, as well as of the living' and, in this continued existence, they become 'a familiar and often homey part of our lives' (Bell 1997: 816). The hauntings keep the former residents' everyday things embedded in a continuous affective relationship and place the collections in a liminal space between the quickness of life and the stillness of death.

\section{A Historic Home}

The Tredwell family and their servants were the only inhabitants of the Merchant's House prior to it becoming a museum. The house is located on Fourth Street, in the Bond Street area, east of Washington Square Park; in the 1820s, this was a fashionable residential neighbourhood. Seabury Tredwell bought the house in 1835. By the 1840s, the area surrounding the house had become more commercial, with families moving to Fifth Avenue and Gramercy Park. The house remained occupied until 1933, when the last remaining Tredwell resident, Gertrude, died. She had lived alone in the house since 1909. Following Gertrude's death, George Chapman, a relative of the family, bought the house together with its contents prior to auctioning it to the Historic Landmark Society, and later transformed the site into a museum.

For almost one hundred years, Tredwells lived inside the house. They made few changes to the original structure and, when the site opened as a museum in 1936, the New York Times commented, 
The Historic Landmark Society acquired the old house in 1935, and found it practically as it was when it had been built. The only changes made in a century were the wiring of the house for electricity (and this had been done only in 1930), the piping of water to the second floor, and the installing of a small furnace. The atmosphere of another century and another way of life pervades it. Nothing has been added to create "atmosphere"; everything in the house "belongs" there (Fuller 1936).

The authenticity of the house is rooted in the affective atmosphere of another time and there appears to be a natural fit between the house and the things inside. This language about the 'atmosphere' of another time continued to appear in later descriptions of the museum; Executive Director Margaret Gardiner described Merchant's House Museum for the New York Times in 1990 as a place where 'the atmosphere is so tangible: It's 1850 and the Tredwells are coming up the stairs. They've just returned from church' (Wing 1990). Those affiliated with the museum note that its immersive nature allows visitors to brush up against a past that is almost present; it is not simply a place to learn about the past, but to experience it and to be affectively bound up in its atmosphere. Director of Operations for Merchant's House Museum, Emily Hill-Wright, echoes this sentiment as a fundamental aspect of the house, 'the museum itself is remarkably intact, and I think that we really pride ourselves on that'. ${ }^{5}$ The museum's website emphasizes this point, stating that the staff maintains 4,500 catalogued objects of the Tredwells inside the home to offer an 'intimate, and authentic look at the life of this $19^{\text {th }}$-century New York merchant-class family'. ${ }^{6}$

\section{A Haunted House}

Ghosts often inhabit liminal places in the world of the living, frequenting the in-between spaces of crossroads, rivers, churchyards, and at boundary lines (Davies 2007: 45-6). ${ }^{7}$ The overlaying of haunted and liminal geographies builds upon to form an interlaced stratigraphy. For example, the boundary lines of parishes were liminal spaces within a Christian geography of England that established these as places outside the churches' land, which, in turn, provided an in-between-space for ghosts to haunt. The places of death and burial also become haunted and liminal spaces - for instance, in England, crossroads served as burial sites for people who had committed suicide and were forbidden from being buried in churchyards (Davies 2007: 51). Similarly, houses are often the sites of hauntings; houses were where the majority of people died, where people mourned, hosted wakes and sat shiva, and where the material of domestic life served as a mnemonic landscape invoking the deceased. Social theorist Martyn Hudson emphasizes that houses contain lives, current and past, and become a place of intersection, a place 'full of invisible borders and boundaries and locations' (Hudson 2017: 78). British historian Owen Davies suggests that the bedroom in particular was a site of hauntings as this was 'where people most often breathed their last, [and] it was also the room where deep emotions were most frequently manifested. It was a place for dreaming, having sex, exchanging intimate confidences and solitary anguish' (Davies 2007: 47-8).

In Merchant's House, many ghostly appearances and hauntings have occurred in the in-between spaces of stairwells, hallways, and doorways or in the intimate sites of bedrooms. While other parts of the house have been sites of spectral encounters as well, these spaces are where ghosts and visitors encounter each other most frequently, layering new relationships across the boundaries of liminal space.

The reputation of the Tredwell home for being haunted has a history within local memory. From its very beginnings as a museum, the Tredwell house had a reputation as somehow outside the everyday domestic landscape of the surrounding neighbourhood. The $1936 \mathrm{New}$ York Times article discussing the atmosphere of the house as 'of another century' concluded that the pervasive mysterious aura predated the opening of the museum:

"Old Merchant's House" became a veritable house of mystery. Its lonely tenant, aging and weak, seldom left her room on the second floor... The blinds were kept closed in the drawing room; the dining room was never used, and the dust of years accumulated. In 1933, Gertrude Tredwell died in the bed in which she had been born. She lacked but twenty-seven days of being 93 years old. Her life had almost spanned that of the house itself (Fuller 1936). 
Rarely seen, Gertrude Tredwell metaphorically haunted the house in her life, but only after her death appeared as a ghost. The first recorded ghost sighting at Merchant's House occurred shortly after Gertrude's death, when children playing outside of 'what they called "the haunted house"' were frightened away when an elderly woman, in an out-of-date dress, whose 'description matched Gertrude... even though she had died over a year prior', flung open the door and angrily shooed them away (Bellov 2007: 2).

As a historic house museum, Merchant's House is situated betwixt and between the past time of the Tredwell home and the present time of the museum. Dan Sturges explains that this makes the house 'as close to a controlled environment as we can get', because every room and everything in the house was used by one family from a single generation, without layers of subsequent residents, materials, alterations, or memories. ${ }^{8}$ While he uses the term 'haunted' to describe Merchant's House, Sturges explains that this is due to a lack of better terminology, but that he does not like its connotations, stating that the term 'gives sort of a negative connotation that something is scary. The Merchant's House isn't a scary place... it's still a home, and it's still a home to the Tredwells and to the servants that work there'. ${ }^{9}$ When there are more agitating or negative experiences with the ghosts at Merchant's House, they tend to be family members' expressions of dissatisfaction with changes to the house. In March 1991, during renovation, the furniture and collections of the house had to be packed away; however,

as the work progressed members of the museum staff became increasingly aware of strong, almost angry, energy - so powerful that at times it required great strength of will to climb the stairs... the sense of ill boding and hostility was occasionally so oppressive, staff members would find excuses not to climb the stairs (Bellov 2007: 13).

In 1992, a psychic was invited by the museum administration to mitigate this negative energy, and she was able to contact one of the Tredwell daughters who was worried that her father's house was being destroyed:

The psychic explained out loud that the necessary repairs were being carried out and that the house would soon be in better condition than it had for many years. She also reassured the presence that the people in the house loved it dearly and were doing everything possible to ensure its survival. She sensed the entity calming down (Bellov 2007: 19).

After this, the hauntings no longer manifested as hostile or malevolent (Bellov 2007: 19).

Outside the museum, substantially more traumatic ghost stories have circulated in the public sphere. However, the museum staff do not wish to cultivate this understanding of the ghosts, and they explicitly reject reports that contradict the histories of the family and the architecture of the home. Hill-Wright notes,

For years, and this doesn't seem to be the case anymore, [and] I do listen very closely, paranormal walking tours of the East Village will stop outside the Merchant's House and they'll talk about the house and for a long time... there [were] some stories of, like, strangled babies, or tunnels to the East River, just fabricated stories, and so I think we have tried really hard to make sure that anything we share about ghosts in the house comes from something with a source. Something that we can say, like, you know this person experienced this through this person, rather than just sort of sensational unfounded history. ${ }^{10}$

Many of these more sensational stories that Hill-Wright rejects are framed around the trapdoor located on the bedroom floor, claiming that it led to the East River for smuggling, or for the Underground Railroad, or, more generally, for illicitly sneaking in and out of the house. However, the trapdoor simply leads to a small shaft that allows staff to fix the pocket doors on the floor below that often came off their tracks and needed to be realigned. ${ }^{11}$ Thus, those who work at the museum provide, in their relationship with the home and the ghosts, an alternative to the violent and scary stories of a haunted house. 


\section{Ghostly Residents: Gertrude's Haunting and Continuity in Death}

The staff of Merchant's House share stories of ghostly encounters only if they fit within the structures of the home and the lives of those who lived within it. Stories that rely upon architectural fabrications or narratives of family members that are demonstrably unfounded are not part of the accounts the museum maintains in their records and oral accounts. Indeed, instances of encountering ghosts at Merchant's House typically take the form of sensorial experiences that suggest the continuation of the Tredwells' every day mundane activities, such as the footsteps along the hallways and the cigar smoke in the study (Bellov 2007). Less common are sightings of the ghosts that are recognizable from portraits as members of the family. The museum keeps records of these encounters and proudly notes that their "body count is up to five now. ${ }^{12}$ Within the wide-ranging reports of spectral activity in the house, Gertrude is the most prominent:

\section{She's a nice figure for us, we love - not just on ghost tours, but in any programming - to centre Gertrude, in a way that we don't always centre her older siblings, although we do talk about them. ${ }^{13}$}

Gertrude lived as a reclusive woman outside the normative trajectory of women in the nineteenth century. Cultural historian Elizabeth Wilson notes the motif of unmarried women in literature of uncanny or haunted houses, writing, 'the house - the home - is no haven for the unmarried woman, who remains an anomaly and out of place, her instability even feeding the disturbance of the house' (Wilson 2013: 118). Gertrude is silent on the affective experience of remaining in the family house. However, her increasing withdrawal from society and her characterization by family members suggests an experience of profound isolation and loneliness. George Chapman, when asked to describe Gertrude, said, 'read Dickens' description of Miss Faversham (sic.) in Great Expectations and you'll have a pretty good idea of Cousin Gertrude amid her cobwebs and shrouds of dust' (Erskine 1953: 163). Miss Havisham who, after being left on her nuptial day, sits in her wedding dress within her decaying house still decorated for the cancelled event, is emblematic of the indeterminate status of the unmarried women that Elizabeth Wilson discusses in the context of haunting - unable to leave the space of their childhood and find space outside the traditional path of women's lives in the Victorian era.

Gertrude had limited options to move away from her childhood home, and she was born and died in the same bed. ${ }^{14}$ According to family lore, a British man named Luis Walton courted Gertrude, but Seabury Tredwell forbade the marriage, possibly due to Walton's Catholicism, his profession as a physician, or his Irish heritage - all potentially negative attributes to the Episcopalian Seabury Tredwell. ${ }^{15}$ Neither Luis nor Gertrude ever married; Luis had a successful medical career in New York City and travelled frequently back to London, where he was a member of a gentlemen's social club, and Gertrude remained in the house. In her 1953 book Out of This World, about recluses in New York City, Helen Worden Erskine presents an alternative account of Luis Walton and Gertrude. In her book, Erskine recounts conversations with George Chapman wherein George suggested that the trapdoor mentioned earlier led to a secret passage in which a man's coat was found (Erskine 1953: 173). Erskine observes, 'It was easy enough for Dr. Walton to enter this bedroom from that passageway' (Erskine 1953: 176). While Merchant's House Museum staff is emphatic that there is no such secret passageway, it was clearly established in the family's own lore after Gertrude's death.

The New York Times article published the same year as Erskine's book states, 'Miss Tredwell never became part of the world that grew up around her'. The house that, like her, stopped receiving visitors and preserved her isolation became separate from the world around her (Berger 1952). The peripheral and displaced position of the unmarried woman places her in a liminal female domestic space, a space also for ghosts and hauntings (Liggins 2020). Anna Lepine calls attention to the liminal position of the Victorian spinster,

on the one hand, as a woman who did not preside over a domestic space owned by her husband, the spinster was also a displaced person, wandering in search of a home over which to preside; on the other hand, since women were understood as innately domestic, the spinster had an uncanny ability to make herself at home wherever she went... the spinster [came] to be understood as having an odd ability to infiltrate and appropriate peripheral spaces (Lepine 2010: 122). 
Gertrude's liminality becomes manifest in the house as she appears as a ghost after her death, but this was prefigured in her life. The Tredwell home was not a site of traumatic violence but, in the home, there were also experiences of profound alienation and isolation. The house is bound up in the intimacies of a home that was at once welcoming and oppressive.

The complex and intense emotions of the home that Davies suggests facilitate the haunting of a place are certainly present in Gertrude's story. The durational isolation of her life in the house and her life as a reclusive woman never leaving her childhood home layer affective experiences on the geography of the house. Gordon argues, "haunting is a frightening experience', reflecting on the violence and trauma that may continue to leak into the present as unresolved and disturbed pasts (Gordon [1997] 2008: xvi). However, Sturges and HillWright are adamant that the Merchant's House ghosts are not haunting the house as a place of violence, but as a place of intimacy. Sturges acknowledges that although there is certainly something eerie about the house, there is 'no real animosity' and the ghosts come and go of their own free will. ${ }^{16}$ Sturges points out, for example, that the summers are typically quieter around the house with fewer ghosts present because, '[Merchant's House Museum] doesn't have air conditioning... and it's been 112 degrees in some of the rooms and it's oppressive and why they hell would you want to hang around?... I think the spirits are, like, well I'm out of here too! ${ }^{17}$ In contrast to the hot summers, Sturges notes that, for example, around the winter holidays, particularly around the museum's Victorian Christmas events, there is the most spectral activity in the house, stating, 'the way they decorate the house for Christmas is beautiful, and I think the family appreciates that [and] when you walk in there it's a different mood... it's a happy mood'.18 The ghosts follow patterns of coming and going that coincide with the environment of the house. The home is not a prison trapping the ghosts; rather, it 'just became somebody's home again. It just so happens that the owners don't have bodies anymore and occasionally pop by to see how things are going.'19

\section{A Phenomenology of Ghosts in the Museum}

Within the museum, the Tredwells are an active presence. ${ }^{20}$ When the museum installed a new stove in the kitchen, Gertrude Tredwell was seen by a staff member attempting to pull it out of the wall. ${ }^{21}$ Theodor Adorno writes, '[m] useum and mausoleum are connected by more than phonetic association. Museums are like the family sepulchres of works of art' (Adorno 1983: 175). He adds that museal, the German word for museum-like, 'described objects to which the observer no longer has a vital relationship and which are in the process of dying' (Adorno 1983: 175). Adorno suggests that these fading objects are stored in sepulchre museums as relics of history and not of a living world; however, the living world of Merchant's House Museum is also animated by the dead. The Nunns and Fischer rosewood piano in the parlour was unplayable due to its condition, and yet spectral music was frequently heard by visitors and passers-by; once the museum decided to restore the piano to allow it to be playable, the music stopped being heard (Bellov 2007: 9-10). ${ }^{22}$

Ghosts and haunting rely upon a phenomenological methodology where the intimacy of experience and the conscious recognition of spectrality form the foundations of how we know the haunted. Michele Hanks explains, 'to know a ghost required either experiencing one or hearing about someone's experience with one' (Hanks 2015: 14-5). At Merchant's House, the experiences of haunting are not limited to the time and space of ghost tours; rather, the ghosts permeate the space of the museum and are not narrative creations meant to sensationalize the museum. Hill-Wright notes that historically, there has been a rejection of the haunted nature of the museum; in the 1960s and 1970s the docent training manual had a warning in large letters stating, 'DO NOT TALK ABOUT GHOSTS!'23 Nevertheless, the presences persisted. By the early 2000s, the museum staff began to talk about their ghosts and became 'at the front edge of the ghost tour in a historic place [in New York City]'. ${ }^{24}$ Initially motivated by a desire to bring new audiences into the museum, the interest in the museums' ghosts has grown substantially over the years and become a critical part of the museum's work. ${ }^{25}$ Now, all the docents are expected to have a repertoire of ghost stories to tell, although not all of them are equally interested in the haunted aspects of the house. Nevertheless, Hill-Wright emphasizes that it is important to the museum that no one is made to feel out 
of place for asking about ghosts or for attending the museum to experience it as a haunted space. ${ }^{26}$ For some of the docents, there can be a tension between the historical and haunted aspects of the house. Hill-Wright notes that not all the volunteers are comfortable speaking about the ghosts as many 'are people who love history' and some find the transition to the oral and experiential accounts of ghosts a challenge. ${ }^{27}$ Hanks notes that 'a tension emerges between knowledge and experience in ghost tourism...as well as understandings of who has the epistemological authority to narrate the past' (Hanks 2015: 14-5). For the museum, it is important when sharing the ghost experiences with the public 'to be as authentic to the stories as possible... we didn't want it to feel like we were fabricating anything, ${ }^{28}$

The value of authenticity in the experience of ghost encounters is central to the structure of the Merchant's House Museum ghost tours. These are structured around first-person accounts in spaces where hauntings occurred. Visitors record narratives of their paranormal encounters so that others can listen to their testimony. Hill-Wright explains, 'you're hearing it from the horse's mouth, so to speak'. ${ }^{29}$ The ghost tours at Merchant's House are not designed to be frightening or to shock visitors; instead, the tone is more a pervasive eeriness. Visitors are taken through the house with two guides who narrate the history of the haunted house and present the first-person accounts of ghostly encounters. Some tours are conducted by candlelight (now battery powered LED candles, after too much wax dripping on the floors as the tours became popular), and they last approximately an hour, taking guests up to the bedroom floor, up to the servants' quarters in the attic, and then back down to the parlour and into the kitchen. For Merchant's House, it is about presenting an authentic 'record of people in the house telling the stories that happened to them in those spaces'. ${ }^{30}$ The museum does not actively solicit accounts from visitors about their experiences in the house as a haunted space, but it regularly receives new ones. ${ }^{31}$ The museum staff records these accounts, and Anthony Bellov, a member of the Board of Directors, produced an anthology, Some Say They Never Left: Tales of the Strange and Inexplicable at the Merchant's House Museum, which is available for purchase from the museum shop. The museum tries to corroborate stories, for example, when two unconnected visitors on the same day report being followed down the stairs by a ghostly woman in a long black gown. Such accounts are given greater credence than others not only because of the shared experience, but also because they fit into recognized patterns of where and how hauntings occur within the house. These patterns are the result of years of accounts of piano music, cigar smoke, and cold spots. ${ }^{32}$

The museum engages with ghosts year-round in their tours and interactions with visitors; they also feature the ghosts on their website, highlighting the haunted nature of the site to prospective visitors and as a prominent feature of their site interpretation. Approximately 7-12 per cent of visitors come for the ghost tours, though many more visitors are motivated by the ghosts. ${ }^{33}$ While many historic house museums run ghost tours as part of seasonal programming in October to draw in Halloween tourism, Merchant's House avoids isolating them in the ritualized time and space of the Halloween ghost tour. ${ }^{34}$ Nevertheless, the museum does offer more frequent ghost tours in October along with their seasonal exhibition titled Death and Mourning that stages a nineteenth-century funeral in the parlour. This exhibition pre-dates the ghost tours and includes a coffin and funeral decorations laid out as they would have been during the lives of the Tredwells (eight of whom died at home). The home was where death happened in the nineteenth century, and Merchant's House emphasizes this through the tours, exhibitions, and, every March, by hosting Seabury Tredwell's funeral to commemorate his death in 1856. This annual event includes visitors and staff in period costumes, a staff member portraying Eliza Tredwell, and a procession of the coffin to Marble Cemetery located between Second Avenue and Bowery, which is approximately a five-minute walk from the Merchant's House.

At Merchant's House, programming around the ghosts invites visitors into the regular life of the Tredwells. An attitude of anti-sensationalism pervades the museum's engagement with the ghosts; even during their October programming when the demand for spooky and scary events is higher, the museum opts to include an intimate presentation of death in the family by staging a funeral in the parlour. Merchant's House Museum reminds visitors that death occurred within the home, and there was an intimacy with the dead and with death. It emphasizes the spectral, not the spectacular. 


\section{Conclusion}

The museum is a crossroads space, a place between the living and the dead. Museums have served as burial sites and mimicked sepulchral architecture. Museum theorist Carol Duncan notes the architectural echoes of tombs, burial chapels, and mausoleums in museums. Duncan presents museums in general as spaces that invite the visitor to step outside of the everyday world and into a 'time and space in which visitors, removed from the concerns of their daily, practical lives, open themselves to a different quality of experience' (Duncan 1995: 20). Duncan's focus on liminality comes from her engagement with ritual theory to explore the scripted movement, affective experiences, and spatial separation visitors experience in the museum. In some cases, museums have extended this design to become mausoleums serving as actual burial sites. The Dulwich Picture Gallery in London, for example, was built in the early nineteenth-century as a structure with 'stark, unadorned, and often windowless walls [that] consciously evoke tomb sites...' (Duncan 1995: 85). Sir John Soane designed the gallery to entomb the remains of Sir Francis Bourgeois, as well as Noel and Margaret Desenfan and the art they collected. The joining of collectors and collections within a museum was designed to give the 'dead a prolonged existence in the memory of the living' (Duncan 1995: 84). Like the rivers and boundary lines where ghosts haunt the world of the living, museums, too, become spaces where the dead are made present to the living. As memorial spaces, museums participate in a geography of in-betweenness that is fertile ground for ghosts and hauntings.

Merchant's House Museum, as both a home and museum, is twice over embedded in a liminal space between the living and the dead. Historic house museums are liminal sites where the living space of the dead is recreated. The boundary lines between past and present are blurred in the layered histories, and visitors are invited to walk through the in-between-time of then and now. The intimate and immersive liminal environment of Merchant's House has an ensorcelling quality. Ghost encounters and paranormal investigations are often closely attuned to the environmental and experiential nature of a time and place (Davies 2007; Hanks 2015). In Gordon's language, this is the sometimes unwilling and magical draw of haunting that pulls us into a reality we experience (Gordon [1997] 2008: 8). Hill-Wright states,

The house really has a way of making you fall in love with it and a lot of people involved with the house started in one capacity and then just never left... It's just that the house really pulls you in and keeps you there. ${ }^{35}$

Haunted intimacy asks us to consider what relationships can be built within a museum when the dead are welcomed as ontological beings that continue to impact the things that belonged to them; this framework of haunted intimacy is explored within the limited confines of a single museum, but the dead haunt museum collections all over, and when we consider them not as metaphors, but as beings that have demands and desires, our responsibility in stewardship and care shifts to one of relationship-building with the dead. In my research, I only found one example of possession where a ghost entered into the body of another; at the December 2004 Nineteenth Century Holiday Party, a woman announced to the crowded room of carollers and party-goers 'Happy Christmas! Thank you all for coming to my house!' (Bellov 2007: 25). The woman apologetically explained that she had no idea what happened and that she had felt an overwhelming sensation of happiness that everyone had gathered to visit her (Bellov 2007: 25). Clearly, Merchant's House Museum is still a home. The phenomenology of haunting invites an affective relationship rooted in experience and emotion. At Merchant's House Museum, this relationship is one of intimacy where the living and the dead meet to animate the space of the home.

Received: 1 June 2021

Finally accepted: 22 September 2021

\section{Acknowledgements}

Thanks to the staff and volunteers of Merchant's House Museum; in particular, Emily Hill-Wright and Dan Sturges. Their comments are included in this article with permission. I also thank Bruce Altshuler and Rosanna Flouty at New York University's Program in Museum Studies for introducing me to Merchant's House. I am also grateful to the insight and advice of J. 
Barton Scott, Judith Ellen Brunton, Birgit Meyer, Amy Levin, and my anonymous reviewers who have helped shape my work and develop my thoughts. Finally, I thank the students in my seminars Spirit(ual) Collections: Magic, Science, Religion, and the Museum as well as Death, as well as Decay, Destruction: Dark Tourism and Sites of Memory, who shared their insights into haunted museums and heritage sites.

\section{Notes}

1 While the house and its décor are a mixture of Federal and Greek Revival styles, George Chapman (the founder of the museum) was particularly interested in presenting the house as 'purely Federal' and ignored evidence to the contrary, to the extent that when Town and Country wanted to include the house in their list of Greek Revival architectural sites, he turned them down, stating 'We are Federal, period' (Knapp 2016: 7).

2 Emily Hill-Wright, interview by author, digital recording, 26 June 2020, New York City.

3 Ann Haddad, "'The Reign of Benevolence:" Christmas with the Tredwell Family, 1850', Merchant's House (blog), 2018. https://merchantshouse.org/blog/christmas-1850/, accessed 18 June 2021; Ann Haddad (merchantshouse), Instagram post, 15 July 2020. https://www.instagram.com/p/CCqZoDJJCZE/?igshid=1qc8bdxyl2dna 18 June 2021; Merchant's House Museum, 'Behind Closed Doors \& Drawers', Virtual Exhibition. http:// merchantshouse.org/virtual-exhibitions/look-inside/18 June 2021; Ann Haddad, 'The Man That Got Away: Gertrude's Lost Sweetheart', Merchant's House (blog), 10 February 2017. http://merchantshouse.org/blog/luis-walton/, accessed 27 April 2020.

4 Dan Sturges, interview by author, digital recording, 19 July 2020, New York City.

5 Emily Hill-Wright, interview, 26 June 2020.

6 Merchant's House Museum, 'Collections'. Merchantshouse.org/the-house/collections/, accessed 27 April 2020.

7 While Davies is mainly addressing the British tradition of haunting, the connection between liminal spaces and haunting extends well beyond British traditions. There are other works that specifically consider the American context of ghosts (see examples: Bailey 1999; Bergland 2000; Montell 2001; Richardson 2003; Weinstock 2004; Seeman 2019).

Dan Sturges, interview, 19 July 2020.

Dan Sturges, interview, 19 July 2020.

Emily Hill-Wright, interview, 26 June 2020.

11 Emily Hill-Wright, interview, 26 June 2020.

12 Emily Hill-Wright, interview, 26 June 2020. The five identifiable ghosts are Seabury, Eliza, Elizabeth, Samuel, and Gertrude Tredwell.

Emily Hill-Wright, interview, 26 June 2020.

Merchant's House Museum, 'Lingering in the Shadows: Spirits of the Merchant's House Museum, Past \& Present: A Virtual (Otherworldly) Presentation via Zoom', 30 October 2020.

Ann Haddad, 'The Man That Got Away'.

Dan Sturges, interview, 19 July 2020.

17

Dan Sturges, interview, 19 July 2020. 
Dan Sturges, interview, 19 July 2020. Lockwood-Mathews Mansion Museum in Connecticut, the Molly Brown House Museum in Colorado, and Casa Loma in Ontario all offer seasonal ghost tours, ghost hunts, or haunted houses within the museum space. For a comparative discussion of the financial impact of ghost-tourism at historic house museums, see Alvey 2017.

Emily Hill-Wright, interview, 26 June 2020.

\section{References}

Adorno, T.W. (1983) 'Valéry Proust Museum’ in Prisms, 175-185, Cambridge: MIT Press.

Alvey, E. (2017) 'Gone Haunting: Exploring the Use of Mission-based Ghost Tours in Historic House Museums', MA thesis, University of Washington, Washington.

Bachelard, G. (2014) The Poetics of Space, trans. Maria Jolas, New York: Penguin Books.

Bailey, D. (1999) American Nightmares: The Haunted House Formula in American Popular Fiction, Madison: The University of Wisconsin Press.

Bell, M.M. (1997) 'The Ghosts of Place', Theory and Society, 26 (6) 813-36.

Bellov, A. (2007) Some Say They Never Left: Tales of the Strange and Inexplicable at the Merchant's House Museum, New York: Merchant's House Museum. 
Berger, M. (1952) 'There's Still a Ghost of a Chance Old Merchant's House Near the Bowery May Be Haunted', New York Times, November 27.

Bergland, R.L. (2000) The National Uncanny: Indian Ghosts and American Subjects, Hanover, New Hampshire: University Press of New England.

Bucior, C. (2020) ‘History's Priests, History’s Magicians: Exploring the Contentious Relationship Between Authorized Heritage and Ghost Tourism in Gettysburg, Pennsylvania', Journal of Heritage Tourism, 15 (3) 328-40.

Davies, O. (2007) The Haunted: A Social History of Ghosts, New York: Palgrave Macmillan.

Derrida, J. ([1994] 2006) Spectres of Marx: The State of Debt, the Work of Mourning and the New International, New York: Routledge.

Duncan, C. (1995) Civilizing Rituals: Inside Public Art Museums, New York: Routledge.

Erskine, H.W. (1953) Out of This World: A Collection of Hermits and Recluses, New York: G.P. Putnam's Sons.

Freccero, C. (2007) 'Queer Spectrality: Haunting the Past', in George E. Haggerty and Molly McGarry (eds) A Companion to Lesbian, Gay, Bisexual, Transgender, and Queer Studies, 194-213, Malden: Blackwell Publishing.

Fuller, R.N. (1936) 'A Landmark and Museum', New York Times, May 3.

Gordon, A. ([1997] 2008) Ghostly Matters: Haunting and the Sociological Imagination, Minneapolis: University of Minnesota Press.

Hanks, M. (2015) Haunted Heritage: The Cultural Politics of Ghost Tourism, Popularism, and the Past, Walnut Creek: Left Coast Press.

Holbraad, M. and Pedersen, M.A. (2017) The Ontological Turn, New York: Cambridge University Press.

Hudson, M. (2017) Ghosts, Landscapes and Social Memory, New York: Routledge.

Inglis, D. and Holmes, M. (2003) 'Highland and Other Haunts: Ghosts in Scottish Tourism', Annals of Tourism Research, 30 (1) 50-63.

Knapp, M.L. (2016) Miracle on Fourth Street: Saving an Old Merchant's House, New York: Girandole Books and the Merchant's House Museum.

Kolk, H.A. (2020) 'Negative Heritage: The Material-Cultural Politics of the American Haunted History Tour', Journal of Cultural Geography, 37 (2) 117-56.

Lepine, A. (2010) '“Strange and Rare Visitants": Spinsters and Domestic Space in Elizabeth Gaskell's Cranford', Nineteenth-Century Contexts: An Interdisciplinary Journal, 32 (2) 121-37.

Liggins, E. (2020) The Haunted House in Women's Ghost Stories: Gender, Space and Modernity 1850-1945, Cham: Palgrave Macmillan.

Lipman, C. (2014) Co-Habiting with Ghosts: Knowledge, Experience, Belief and the Domestic Uncanny, Burlington, Vermont: Ashgate.

Miles, T. (2015) Tales from the Haunted South: Dark Tourism and Memories of Slavery from the Civil War Era, Chapel Hill: The University of North Carolina Press. 
Montell, W.L. (2001) Haunted Houses and Family Ghosts of Kentucky, Lexington: University Press of Kentucky.

Morrison, T. ([1987] 2004) Beloved: A Novel, New York: Vintage International.

Oram, A. (2012) 'Going on an Outing: The Historic House and Queer Public History', in Jerome de Groot (ed) Public and Popular History, 41-60, London: Routledge.

Richardson, J. (2003) Possession: The History and Uses of Haunting in the Hudson Valley, Cambridge, Massachusetts: Harvard University Press.

Seeman, E.R. (2019) Speaking with the Dead in Early America, Philadelphia: University of Pennsylvania Press.

Vagnone, F.D. and Ryan, D.E. (2016) Anarchist's Guide to Historic House Museums, Walnut Creek: Left Coast Press.

Weinstock, J.A. (2004) Spectral American: Phantoms and the National Imagination, Madison: University of Wisconsin Press.

Wilson, E. (2013) 'Haunted Houses', AA Files, 67 113-8.

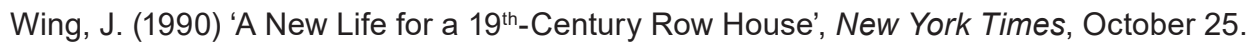

Woolf, V. (1921) 'A Haunted House', in Monday or Tuesday, 3-7, New York: Harcourt, Brace and Company.

\section{Author}

Marisa Karyl Franz

marisa.franz@nyu.edu

ORCID iD: https://orcid.org/0000-0002-6088-8123

URL: https://as.nyu.edu/faculty/Marisa.html

Faculty Fellow in Museum Sstudies

New York University

United States

Marisa Karyl Franz holds a Ph.D. in religious studies from the University of Toronto and is currently a faculty fellow in museum studies at New York University. 